\title{
Development of Leading Sectors and Competitiveness of Animal Husbandry Commodities in Banjarbaru City 2010-2016
}

\author{
Muhammad Muhaimin ${ }^{1 *}$ Akhmad Ramali ${ }^{1}$ \\ ${ }^{1}$ Geography Education Department, Faculty of Teacher Training and Education, Lambung Mangkurat University, \\ Banjarmasin, Indonesia \\ ${ }^{*}$ Corresponding author.Email: muhammad.muhaimin@ulm.ac.id
}

\begin{abstract}
This study aims to identify superior commodities, competitiveness and growth structure patterns of the livestock sector in the City of Banjarbaru in 2010-2016. The approach used in this research is a descriptive quantitative approach. The data used in this study are secondary data, namely the production results of each commodity in the livestock sector from 2010 to 2016. The analytical techniques used are Location Quotient (LQ), Shift Share (SSA), and Typology Klassen. The livestock sector in Banjarbaru City in 2010-2016 which is the leading commodity based on the Location value Quotient highest and has competitiveness against other commodities based on Shift Share analysis is the Layer Chicken Commodity. The condition of the growth pattern and structure of the livestock sector in the City of Banjarbaru in 2010 - 2016 is in quadrant 2 for Pigs, Chickens, Quail and Geese. Quadrant 3 for commodities of buffalo, layer hens and ducks. Quadrant 4 for Cattle, Goat, and Domestic Chicken Commodities.
\end{abstract}

Keywords: Competitiveness, Animal Husbandry, Location Quotient, Shift Share, Klassen Typology

\section{INTRODUCTION}

The process of economic development does not happen by itself, but requires various efforts from various parties. The main objective of economic development is to increase production in each of the leading economic sectors of the region [1]. An indicator of ongoing economic development in a region is the existence of economic growth in that region. The rate of economic growth indicates the success or failure of a region's economy [2]. Regional economic development activities do not only focus on the regional economy in general, but deep attention also needs to be given as an effort to identify leading sectors [3].

Indonesia consists of several regions that have various economic structures. The economic structure can be seen from the role of each economic sector [4]. The era of regional autonomy requires that a region be able to identify the leading economic sector in the area which is then maximally explored and developed [5]. Banjarbaru City is a contributor to the economic sector in South Kalimantan Province which has experienced the highest economic growth in Indonesia since the third quarter of 2017 [6]. According to the Regional Development Planning, Research and Development Agency (BAPPEDA) of Banjarbaru City, the sector livestock is the mainstay of the economy of Banjarbaru City because it is experiencing growth and tends to be developed, its implementation requires identification and analysis of the livestock sector.

\section{THEORETICAL FRAMEWORK \\ 2.1 Economic Leading}

Sector A leading economic sector is a sector that has high resilience and capability so that it can serve as a foundation for economic development expectations. A leading sector is the backbone and driving force of the economy, so it can also be called a key sector or the leading sector of the economy of a region. The leading sector is a reflection of an economic structure, so that it can also be seen as one of the characteristic aspects or characteristics of an economy.

\subsection{Location Analysis Quotient (LQ)}

Analysis is an economic development tool simple and basic with all its advantages and limitations and this method is a method commonly used in economic models as a first step to understanding the activity sectors that trigger growth. LQ analysis measures the relative concentration or degree of specialization of economic activity through a comparative approach [7].

\subsection{Shift Share Analysis (SSA)}

Analysis Shift Share Is an analysis tool to identify economic sources in terms of labor or income in a particular region. This Shift Analysis Share Is useful for viewing regional developments towards a wider area, for example the development of districts against provinces or provinces against the national. Shift Share analysis also compares the growth rate of various commodities in a region against the national territory (or a higher level). 
Shift Analysis is Share Considered sharper than Location Analysis Quotient Because it details the causes of changes in several variables. The results of the Shift Share analysis will be more accurate when supported by the results of the Location Quotient analysis [8].

\subsection{Klassen's Typology}

Analysis of typology is used to see an overview of the growth patterns and structures of each economic sector. This description of the pattern and structure of regional growth can be used to estimate the prospects for regional economic growth in the future. In addition, this can also be used as a material consideration in determining regional development policies [9].

\section{METHOD}

\subsection{Study Area Description}

Astronomically Banjarbaru City is located between $3^{\circ} 25^{\prime} 40$ " - 3 $28^{\prime} 37$ " South Latitude and 114 $41^{\prime} 22$ " $114^{\circ} 54^{\prime} 25^{\prime \prime}$ East Longitude. Administratively, the City of Banjarbaru is located between two districts, the north, the east, and the south bordering Banjar Regency and the south bordering Tanah Laut Regency [10]. The map of the research location is presented in Figure 1.

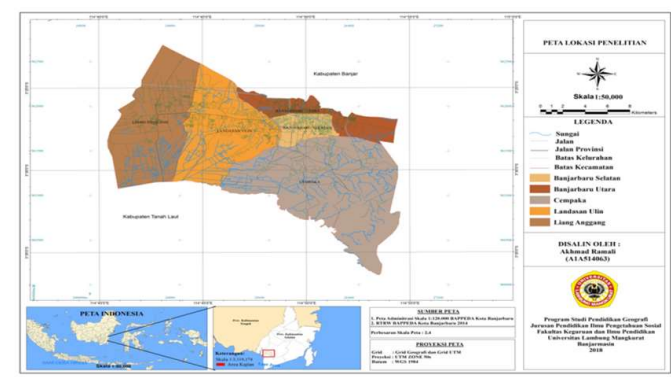

Figure 1 Map of Banjarbaru City

\subsection{Population and Sample}

The population in this study were all livestock commodities in Banjarbaru City, South Kalimantan Province, namely buffalo, cows, goats, pigs, native chickens, laying hens, broilers, quails, geese, and ducks. The sample in this study is a full sample or the whole of the population.

\subsection{Data Collection The data}

used in study this are secondary data. Secondary data collection techniques used document studies by visiting related agencies. Secondary data in this study of data from the livestock sector of commodity production Banjarbaru from years 2010-2016 obtained from the Department of Agriculture and Forestry, the Central Statistics Agency (BPS) and the Agency for Development Research Planning and Development (BAPPEDA) Banjarbaru.

\subsection{Analysis of Data}

Research on Leading Sector Development and Competitiveness of Animal Husbandry Commodities in the City of Banjarbaru in 2010-2016 using three data analysis techniques. Location analysis is Quotient (LQ)used to determine which commodities are base or superior [7]. Shift Share (SSA) analysis is used to determine competitive commodities [8]. Analysis is typology Klassen used to determine the pattern and structure of growth in commodity production [9].

\section{RESULTS AND DISCUSSION 4.1 The Leading Sector of Animal Husbandry in Banjarbaru City 2010-2016}

The results of the calculation will show that a commodity is classified as basis (superior) or non basis (not superior) in each district, which is indicated by the value of Location Quotient (LQ)> 1. The structure of the Location Quotient (LQ) formulation provides the following values:

LQ $>1$ : It is a basic commodity, meaning that the production of commodity (i) is higher than the level of production of other commodities in the same sub-district. Thus, commodity (i) is a leading commodity to be further developed in the region.

LQ $<1$ : It is a non-base commodity, meaning that the production of commodity (i) is lower than the level of production of other commodities in the same kecamatan. Thus, commodities (i) is not a main commodity for further development in the region [11].

The Location Analysis Quotient (LQ)of the livestock sector commodities in the City of Banjarbaru in 2010, it was found that in 2010 included in the basic category were Cattle, Goats, Domestic Chickens, Laying Chickens, Quail and Ducks. The Location analysis Quotient (LQ)of the livestock sector commodities in the city of Banjarbaru in 2011 found that in 2011 included in the basic category were buffalo, cattle, goats, native chickens, laying hens, quails and ducks. The Location analysis Quotient (LQ)of the livestock sector commodities of Banjarbaru City in 2012 found that in 2012 included in the basic category were buffalo, cattle, goats, native chickens, laying hens, quail, geese and ducks. The Location analysis Quotient (LQ)of livestock sector commodities in Banjarbaru City in 2013 found that in 2013 included in the basic category were buffalo, cattle, goats, domestic chickens, laying hens, quail, geese and ducks. The Location analysis Quotient (LQ) of the livestock sector commodities in the city of Banjarbaru in 2014 found that in 2014 included in the basic category were buffalo, cattle, goats, native chickens, laying hens, quail, geese and ducks. The Location analysis Quotient (LQ)of the livestock sector commodities in the city of Banjarbaru in 2015 found that in 2015 included in the basic category were buffalo, cattle, goats, native chickens, laying hens, quail, geese and ducks. The Location Analysis Quotient (LQ) of livestock sector commodities in the City of Banjarbaru in 2016, it was found that in 2016 included in the basic category were buffalo, cattle, goats, domestic chickens, laying hens, quail, geese and ducks. The Location Quotient (LQ) value of the livestock sector commodities in the City of Banjarbaru from 2010-2016 is detailed in Table 1. 
Table 1 The Location Quotient Value for the Livestock Sector Commodity of the City of Banjarbaru, 2010-2016

\begin{tabular}{lccccccc}
\hline \multirow{2}{*}{ No } & & \multicolumn{7}{c}{ District } \\
\cline { 3 - 6 } & Commodities & Ulin & Liang Anggang & Cempaka, & North Banjarbanu & South Banjarbaru & Average of \\
\hline 1 & Buffalo & 0.00 & 4.93 & 0.00 & 0.76 & 0.00 & 1.14 \\
2 & Cows & 0.53 & 1.07 & 3.54 & 2.84 & 0.38 & 1.67 \\
3 & Goats & 0.48 & 2.33 & 2.47 & 1.62 & 0.33 & 1.45 \\
4 & Pigs & 2.02 & 0.00 & 0.00 & 0.00 & 0.000 .00 & 0.40 \\
5 & Natural Chickens & 0.51 & 1.45 & 2.28 & 1.22 & 1.11 & 1.31 \\
6 & Slaughtered Chickens & 1.06 & 0.94 & 0.64 & 0.99 & 1.03 & 0.93 \\
7 & Laying Chickens & 0.20 & 0.07 & 13.34 & 0.00 & 0.00 & 2.72 \\
8 & Quail & 0.52 & 2.36 & 2.53 & 2.14 & 0.07 & 1.52 \\
9 & Geese & 0.71 & 0.27 & 1.28 & 2.76 & 1.53 & 1.31 \\
10 & Ducks & 0.51 & 1.91 & 3.37 & 1.18 & 0.57 & 1.51 \\
\hline
\end{tabular}

Results of Table 1 analysis, seen from the average magnitude of the Location Quotient (LQ) for livestock commodities in Banjarbaru City, 2010-2016, the commodity that has the Location Quotient highest (LQ) value is Layer Chicken Commodities (2.72), so that the commodity can be categorized as an as a commodity that is superior compared to other commodities.

\subsection{Competitiveness of the Livestock Sector of the City of Banjarbaru in 2010-2016}

Shift Share (SSA) analysis shows that of all types of commodities analyzed, there are four commodities that have positive production growth, one commodity has negative production growth and five commodities have zero production growth (0). Commodities that have competitiveness are those that have the capacity for the highest positive production growth. (Porter, 1996) Consecutively, the livestock sector commodities of Banjarbaru City in 2010-2016 which had the highest to lowest competitiveness according to the SSA analysis were Layer Chickens (1530.00), Quail (180.00), Cows (132.36). and Chicken (38.30). The results of the Shift Share (SSA) analysis of the livestock sector in the City of Banjarbaru for 2010-2016 are detailed in Table 2.

Table 2 Value of Shift Share (SSA) for the livestock sector in the City of Banjarbaru in 2010 - 2016.

\begin{tabular}{|c|c|c|c|c|c|c|c|}
\hline \multirow[b]{2}{*}{ No } & \multirow[b]{2}{*}{ Commodity } & \multicolumn{5}{|c|}{ District } & \multirow[b]{2}{*}{ Average of } \\
\hline & & Ulin & Liang Anggang & Cempaka & North Banjarbaru & South Banjarbaru & \\
\hline 1 & Buffalo & 0 & 7 & -7 & 0 & 0 & 0 \\
\hline 2 & Ox & $293.6391 .2-70.3132 .36$ & & & & 21.3 & 26 \\
\hline 3 & Goats & $-165.5-98.3$ & 101.9 & 117.7 & & 44.2 & 0 \\
\hline 4 & Pig & 0 & 0 & 0 & 0 & 0 & 0 \\
\hline 5 & Native Chicken & $-1840.2-1071.4-5535.56126 .1$ & & & & 1871 & -90 \\
\hline 6 & Chicken Cut & $-20051.2-442.7-68206.41162 .7$ & & & & 87729.1 & 38.3 \\
\hline 7 & Chicken Laying & 9635.3 & 2500 & -4585.3 & 100 & 0 & 1530 \\
\hline 8 & quail & $-1457.5-321.5-1289.8-959.2$ & & & & 4928 & 180 \\
\hline 9 & Goose & -220.5 & 43.7 & 44.5 & 96.4 & 35.9 & 0 \\
\hline 10 & Ducks & 879.4 & 162.5 & 3461.3 & -2555.5 & -1947.7 & 0 \\
\hline
\end{tabular}

Determination of the competitiveness of the livestock sector in the City of Banjarbaru in 2010-2016 by using the Shift Share (SSA) analysis, it was found that the commodity in the livestock sector of Banjarbaru City in 2010-2016 which had competitiveness against other commodities was Layer Chickens. Commodity Layer Chicken as a commodity that has competitiveness as well as a leading commodity based on Location Analysis Quotient (LQ). The distribution of the potential for livestock sector commodities based on the Location analysis is Quotient (LQ) and Shift Share (SSA)presented in Fig 2. 


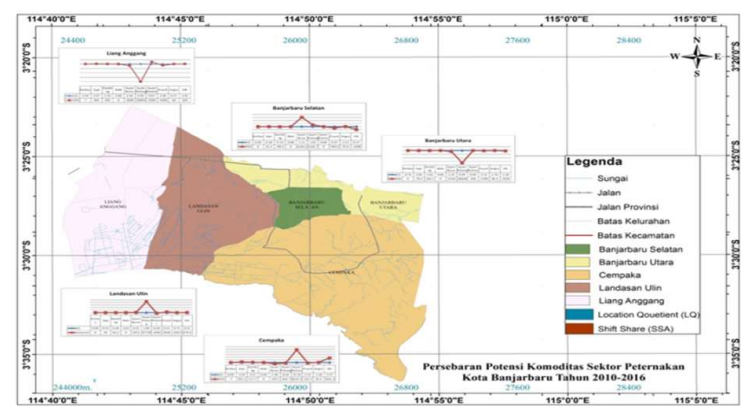

Figure 2 The distribution of the potential for livestock sector commodities based on the Location Analysis of the Quotient (LQ) and Shift Share (SSA)

\subsection{Patterns and Growth Structure of City Livestock Banjarbaru 2010-2016}

Analysis Typology Klassen categorizes commodities into four classifications known as quadrants. Quadrant 1 is for developed and rapidly growing commodities, quadrant 2 is for developed but depressed commodities, quadrant 3 is for commodities with potential and can still be developed and quadrant 4 is for commodities that are relatively lagging behind [9]. Classification Classes are Typology detailed in Table 3 .

Table 3 Typology Classification of Animal Husbandry Sector in Banjarbaru City 2010-2016

\begin{tabular}{ccc}
\hline $\begin{array}{c}\text { Sectoral Contribution } \\
\text { Sectoral }\end{array}$ & gi $>=\mathbf{g}$ & Growth \\
\hline $\mathbf{s i}>=\mathbf{s}$ & Quadrant 1 $<\mathbf{g}$ & Quadrant 2 \\
& - & Pig, Cut Chicken, Goose, Quail \\
\hline $\mathbf{s i}<\mathbf{s}$ & Quadrant 3 & Quadrant 4 \\
& $\begin{array}{c}\text { Buffalo, Laying Chicken, } \\
\text { Ducks }\end{array}$ & Cows, Goats, Domestic \\
Chickens
\end{tabular}

The results of analysis typology Klassen Show that the livestock sector commodities of Banjarbaru City in 20102016 experienced growth which was presented in the quadrant classification. Commodities that are included in the advanced but depressed classification (quadrant 2) are Pig, Chickens, Goose and Quail. Commodities included in this quadrant are commodities whose production growth value in the City of Banjarbaru is smaller than the value of production growth in South Kalimantan, but has a sectoral contribution value in the City of Banjarbaru that is greater than the value of the sectoral contribution of South Kalimantan. Commodities included in the classification of potential and developing commodities (quadrant 3) are buffalo, laying hens and ducks. Commodities included in this quadrant are commodities that have a sectoral growth rate in the City of Banjarbaru that is greater than the sectoral growth rate in South Kalimantan, but has a value sectoral contribution in the City of Banjarbaru that is smaller than the sectoral contribution in South Kalimantan. Commodities included in the commodity classification that are relatively lagging behind (quadrant 4 ) are Cattle, Goats and native chickens. Commodities included in this quadrant are commodities that have a sectoral growth rate and sectoral contributions in the City of Banjarbaru are smaller than the sectoral growth and sectoral contributions in South Kalimantan.

\section{CONCLUSION}

Animal husbandry commodities that are included in the basic or superior category in Banjarbaru City from 20102016 vary in each sub-district unit, but overall the superior commodity in Banjarbaru City is Layer Chicken
Commodities, this is based on the Location Analysis Quotient (LQ)which states that The Layer Chicken Commodity is a commodity with the highest average Location Quotient (LQ) value in the City of Banjarbaru from 2010 to 2016. The livestock sector of Banjarbaru City in 2010-2016 which has the highest to lowest competitiveness according to the analysis Shift Share (SSA)is the Commodity Laying Chickens, Quail, Cattle, and Beef Chickens. The growth pattern and structure of the livestock sector in the City of Banjarbaru in 2010-2016 is based on analysis typology Klassen Which divides into four classifications referred to as quadrants, namely Swine, Chicken, Quail and Goose Commodities which have advanced but depressed production growth (quadrant 2). The commodities of buffalo, laying hens and ducks have potential production growth and can still develop (quadrant 3). Cattle, goats and native chickens have relatively lagging production growth (Quadrant 4). All types of livestock commodities in Banjarbaru City do not have advanced and fast-growing production growth (quadrant 1).

\section{ACKNOWLEDGMENT}

Thank you to the Faculty of Teacher Training and Education for supporting me to join the international conference. Thank you to my colleagues in the Department of Geography Education for being a good colleague.

\section{REFERENCES}

[1] M. L. Jhingan, Ekonomi Pembangunan dan Perekonomian. Jakarta: PT. Raya Grafindo Persada, 2003. 
[2] R. Octaria N and P. Hidayat, "Analisis Sektor Unggulan di Kota Medan,” vol. 3, no. 1, pp. 59-71, 2015.

[3] A. Tabrani, "Analisis Sektor Unggulan Perekonomian Kabupaten Mandailing Natal Provinsi Sumatera Utara," JSTI, vol. 10, no. 1, Art. no. 1, 2008, doi: 10.29122/jsti.v10i1.787.

[4] N. Usya, "Analisis Struktur Ekonomi dan Identifikasi Sektor Unggulan di Kabupaten Subang," 2006, Accessed: Nov. 30, 2020. [Online]. Available: http://repository.ipb.ac.id/handle/123456789/1050

[5] S. S. Khoriah, "Pemetaan Kawasan Pertanian di Kabupaten Hulu Sungai Tengah," Universitas Lambung Mangkurat, 2017.

[6] A. Maudhody, "Pertumbuhan Ekonomi Kalsel Triwulan III 2017 Tertinggi Sejak 4 Tahun Terakhir," Banjarmasin Post, 2017.

[7] R. R. Azwartika and S. Sardjito, "Pengembangan Komoditas Unggulan Pertanian Dengan Konsep Agribisnis Di Kabupaten Pamekasan," Jurnal
Teknik ITS, vol. 2, no. 2, p. 155408, 2013, doi: 10.12962/j23373539.v2i2.4332.

[8] P. Rahayu and A. M. Navastara, "Penentuan Wilayah Potensial Komoditas Jagung Di Kabupaten Kediri," Jurnal Teknik ITS, vol. 3, no. 1, p. 161621, 2014, doi: 10.12962/j23373539.v3i1.5735.

[9] Fachrurrazy, "Analisis Penentuan Sektor Unggulan Perekonomian Wilayah Kabupaten Aceh Utara Dengan Pendekatan Sektor Pembentuk PDRB," 2009, Accessed: Nov. 30, 2020. [Online]. Available: http://repository.usu.ac.id/handle/123456789/7262.

[10] Badan Pusat Statistik, Banjarbaru dalam Angka. 2017.

[11] R. Hendayana, "Aplikasi Metode Location Qoutient (LQ) dalam Penentuan Komoditas Unggulan Nasional," 2003. 